The Common Agricultural Policy of the European Union the present and the future

EU Member States

point of view 



\section{INSTITUTE OF AGRICULTURAL AND FOOD ECONOMICS NATIONAL RESEARCH INSTITUTE}

\section{The Common Agricultural Policy of the European Union - the present and the future}

\section{EU Member States point of view}

Editors:

dr Marek Wigier

prof. dr hab. Andrzej Kowalski

Proceedings of the International Scientific Conference

"The Common Agricultural Policy of the European Union - the present and the future" Multi-Annual Programme 2015-2019

"The Polish and the EU agricultures 2020+. Challenges, chances, threats, proposals" 5-7 December 2017 Stare Jabłonki, Poland

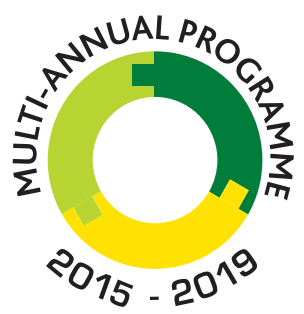

THE POLISH AND THE EU AGRICULTURES 2020+ CHALLENGES, CHANCES, THREATS, PROPOSALS

Warsaw 2018 
This monograph was prepared under the Multi-Annual Programme 2015-2019

"The Polish and the EU agricultures 2020+. Challenges, chances, threats, proposals".

The publication is a collection of selected papers delivered at the 22th edition of the International Scientific Conference organized by the Institute of Agricultural and Food Economics - National Research Institute. The theme of the conference was "The Common Agricultural Policy of the European Union the present and the future. The conference was placed on 5-7 December 2017 in Stary Jabłonki in Poland. Common Agricultural Policy was and still is one of the key pillars of European integration. Published in two volumes materials refer directly to the current and future of the CAP in EU and non EU member states, the strategic objectives and principles of agricultural policy for the agri-food sector and rural areas, address the issues of equilibrium between agriculture, forestry and land use, relate to the dilemmas for the EU budget and the CAP after 2020, CAP instruments and their adjustment, transformations of the rural economy and programming of the rural and agricultural policy, as well as productivity and production efficiency and tensions between sectoral action and between different models of territorial activities.

In the Scientific Committee of the Conference was participated: Prof. Andrzej Kowalski (IAFE-NRI, Poland), Prof. Drago Cvijanonivić (University of Kragujevac, Serbia), Prof. Thomas Doucha (IAEI, Czech Republic), Noureddin Driouech, PhD (CIHEAM, Italy), Prof. Szczepan Figiel (IAFE-NRI, Poland), Prof. Masahiko Gemma (Waseda University, Japan), Prof. Wojciech Józwiak (IAFE-NRI, Poland), Prof. Jacek Kulawik (IAFE-NRI, Poland), Prof. Yuriy Oleksiyovych Lupenko (IAE, Ukraina), Prof. Věra Majerová (CULS, Prague), Prof. Dimitre Nikolov (IAE, Bulgaria), Maire Nurmet, PhD (EMÜ, Estonia), Prof. Gabriel Popescu (ASE, Romania), Norbert Potori, PhD (AKI, Hungary), Prof. Włodzimierz Rembisz (IAFE-NRI, Poland), Piotr Szajner, PhD (IAFE-NRI, Poland), Prof. Alina Sikorska (IAFE-NRI, Poland), Prof. Jonel Subić (IAE, Serbia), Prof. Samuele Trestini (UNIPD, Italy), Prof. Olga Varchenko (Bila Tserkva National Agrarian University, Ukraine), Dipl.-Ing. Klaus Wagner (AWI, Austria), Marek Wigier, PhD (IAFE-NRI, Poland), Prof. Józef St. Zegar (IAFE-NRI, Poland)

In the Organising Committee of the Conference was participated: Małgorzata Bułkowska (IAFE-NRI, Poland), Anna Hankiewicz (IAFE-NRI, Poland), Joanna Jaroszewska (IAFE-NRI, Poland), Joanna Korczak (IAFE-NRI, Poland), Krzysztof Kossakowski (IAFE-NRI, Poland), Irena Mikiewicz (IAFE-NRI, Poland), Małgorzata Mikołajczyk (IAFE-NRI, Poland), Lech Parzuchowski (IAFE-NRI, Poland), Ewa Sierakowska (IAFE-NRI, Poland), Paulina Smakosz (IAFE-NRI, Poland), Leszek Ślipski (IAFE-NRI, Poland), Marek Wigier, PhD (IAFE-NRI, Poland).

Reviewers:

Professor Dimitre Nikolov, Institute of Agricultural Economics, Sofia, Bulgaria

Professor Gabriel Popescu, The Bucharest University of Economic Studies, Bucharest, Romania

Professor Samuele Trestini, University of Padva, Italy

Proofreader

Katarzyna Mikulska

Technical editors:

Joanna Jaroszewska, Barbara Pawtowska, Ewa Sierakowska, Kamila Tomaszewska,

Barbara Walkiewicz

Translated by

Summa Linguae S.A.

Cover Project

Leszek Ślipski

ISBN 978-83-7658-743-1

DOI: $10.30858 / \mathrm{pw} / 9788376587431$

Instytut Ekonomiki Rolnictwa i Gospodarki Żywnościowej

- Państwowy Instytut Badawczy

ul. Świętokrzyska 20, 00-002 Warszawa

tel.: (22) 5054444

faks: (22) 5054636

e-mail:dw@ierigz.waw.pl

http://www.ierigz.waw.pl 


\section{Contents}

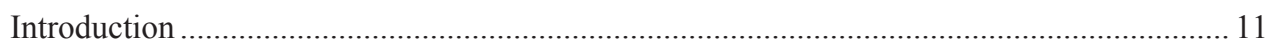

Dr Marek Wigier

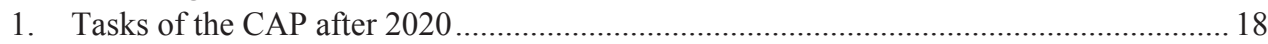

Dr hab. Julian Krzyżanowski

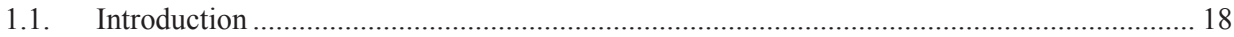

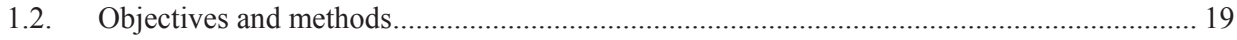

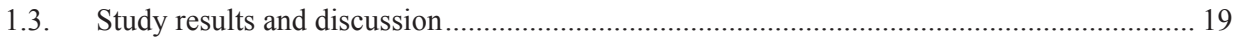

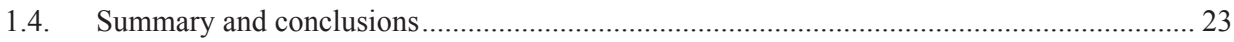

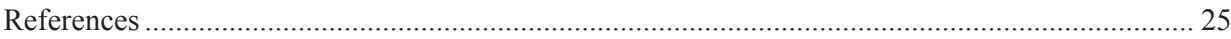

2. An assessment of the regional impacts of post-2020 CAP budgetary cuts on production

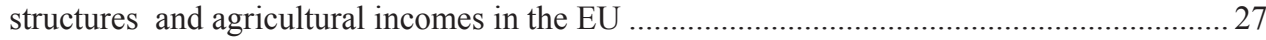

PhD Norbert Potori, PhD János Sávoly, PhD Szabolcs Biró

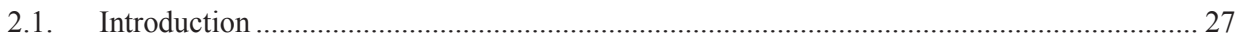

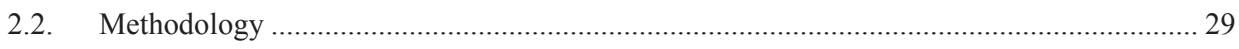

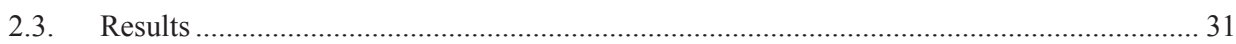

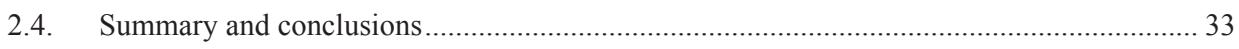

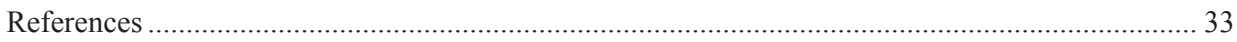

3. Is there room for financial instruments in the Common Agricultural Policy? Casus of

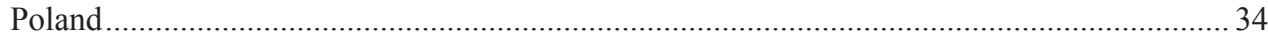

Prof. dr hab. Jacek Kulawik, PhD Barbara Wieliczko, PhD Michat Soliwoda

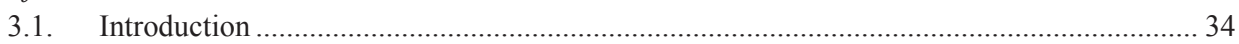

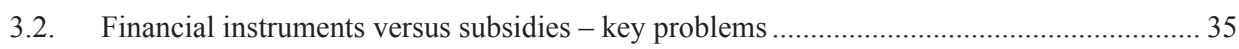

3.3. The use of financial instruments under the EU policy ......................................................... 37

3.4. Example of the use of FI in the 2014-2020 programming period ......................................... 38

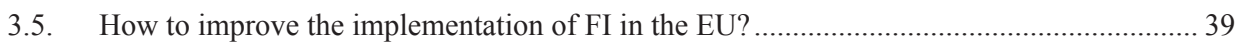

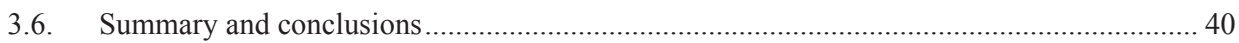

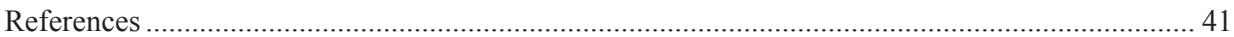

4. The past, present and future of the CAP - the Hungarian viewpoint ............................. 43

Dr Tamás Mizik

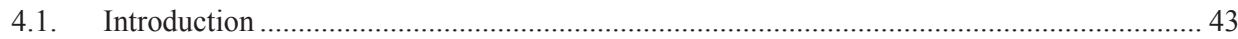

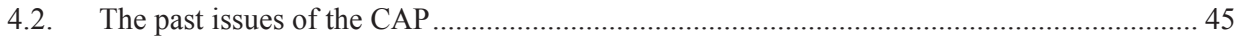

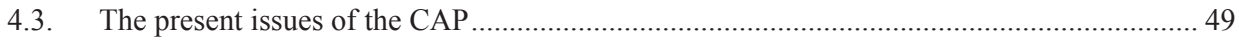

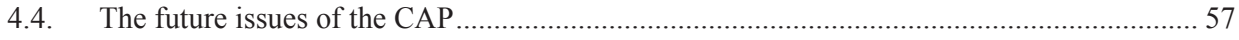

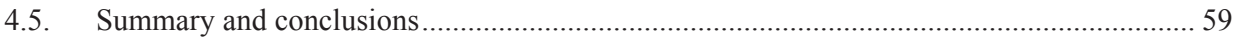

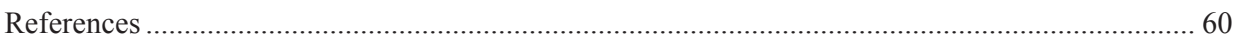


5. Going beyond the Rural Development Programme: a Master Plan for Austria's rural areas in the framework of the CAP

Dip.-Ing. Klaus Wagner

5.1. Introduction

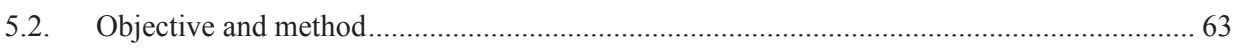

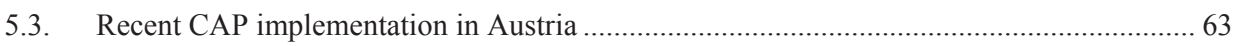

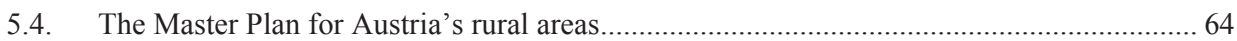

5.5. CAP in the system of the EU policy objectives and in the view of regional science

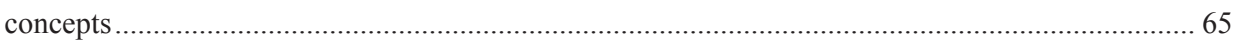

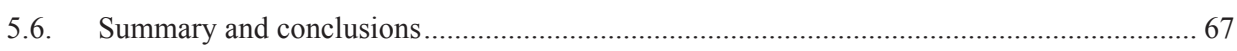

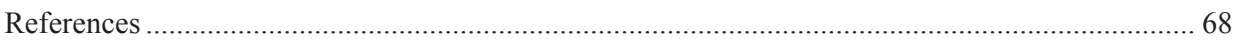

6. Possibilities to connect the Romanian agricultural research to the market requirements 69 Prof. Gabriel Popescu

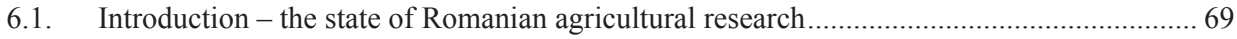

6.2. The problems faced by agricultural research since 1990 ..................................................... 71

6.3. Possible solutions for the recovery of Romanian agricultural research ................................ 76

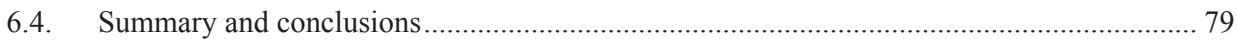

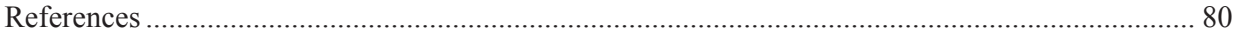

7. Price relationships of the production factors as exogenous determinants of production in agriculture.

Prof. dr hab. Włodzimierz Rembisz, PhD Adam Waszkowski

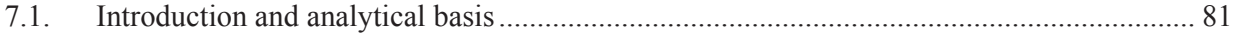

7.2. Relationships of prices of the capital, labour and land factors - hypothetical approach...... 83

7.3. Relationships of prices of the capital, labour and land factors - empirical approach .......... 84

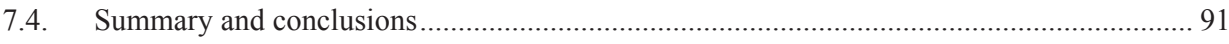

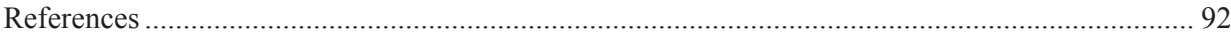

8. Effects of direct payments on agricultural development in Bulgaria ............................. 93 PhD Bozhidar Ivanov

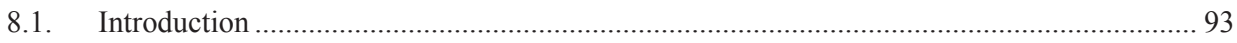

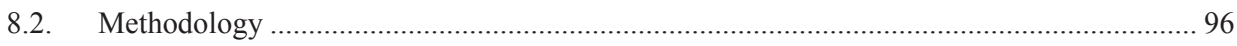

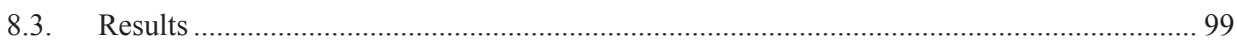

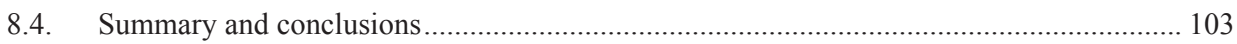

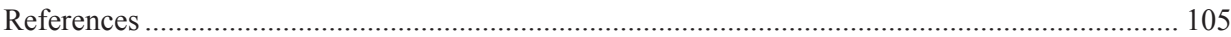

9. Re-adjusting risk management within the CAP: evidences on the implementation of the

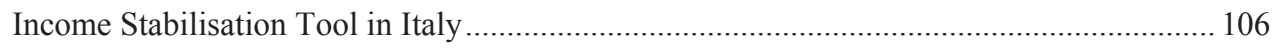
Prof. Samuele Trestini, PhD Elisa Giampietri

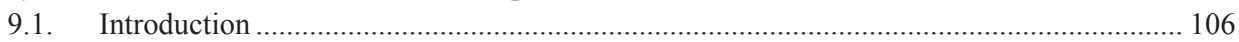

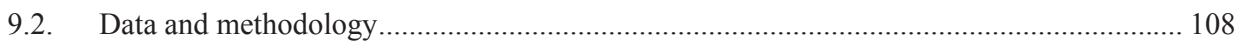




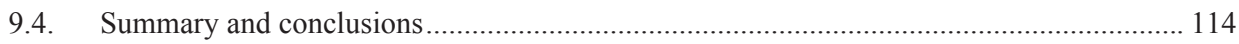

References

10. Comparison of risk management tools under the CAP of the EU, the US Farm Bill

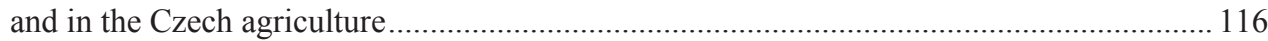
Ing. Václav Vilhelm, CSc., Ing. Sumudu Namali Gouri Boyinová, PhD Jindřich Špička

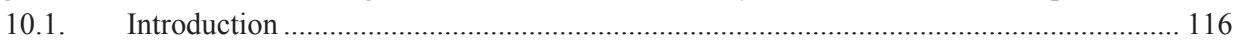

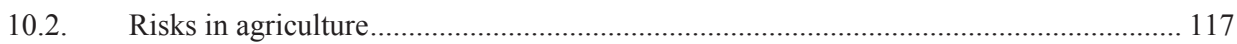

10.3. Risk management policy in the United States Farm Bill 2014 _..................................... 118

10.4. Risk management policy of the European Union's CAP ................................................ 119

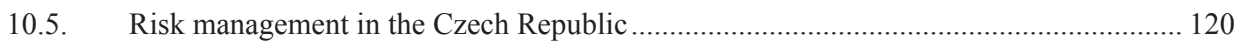

10.6. Comparative analysis of risk management policies ........................................................ 121

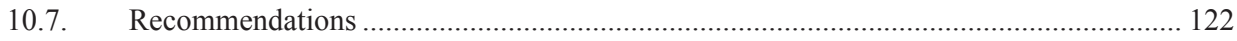

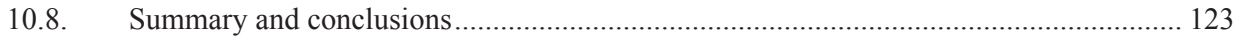

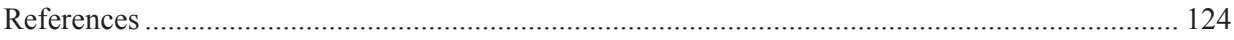

11. Factors determining the crop insurance level in Poland taking into account the level

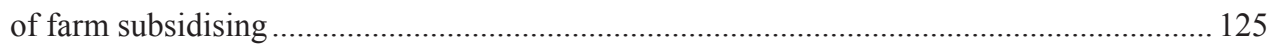

Prof. Adam Was, PhD Pawet Kobus

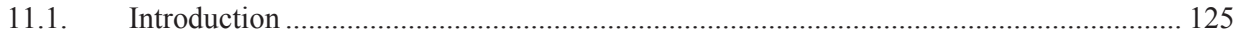

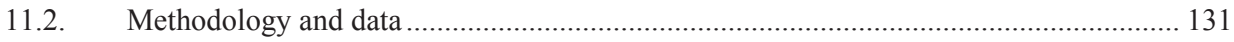

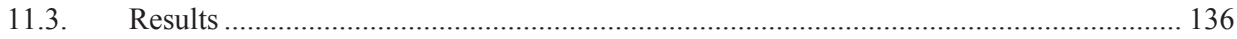

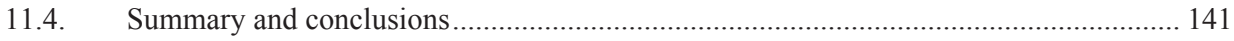

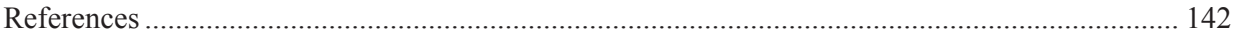

12. Farms and agricultural enterprises for development of sustainable and smart cooperatives: a multifactor approach using digital farm management ............................... 147 Prof. dr habil Adriana Mihnea, Prof. dr Dimitre Nikolov, dr Krasimir Kostenarov

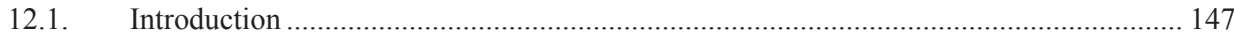

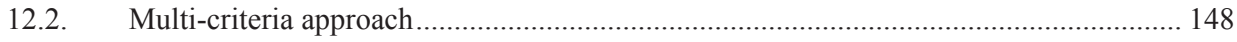

12.3. Construction of Farm Management Model ................................................................ 150

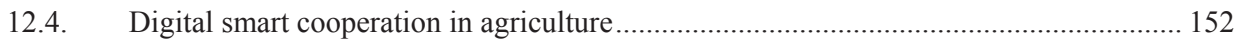

12.5. Application of the ANP Farm Management Model ....................................................... 154

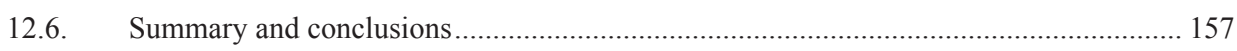

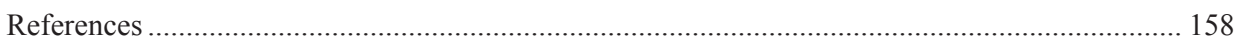

13. Brexit - potential implications for the Polish food sector .............................................. 159

Dr Katarzyna Kosior, Dr Łukasz Ambroziak

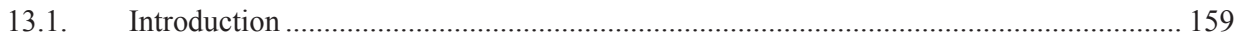

13.2. Negotiations on Brexit - what should be the model of the future relations? ..................... 161

13.3. The future of the EU finances and the CAP in the context of Brexit .............................. 163 
13.4. Impact of possible changes in the CAP budget on the net balance of Poland and transfers to the Polish agriculture.

13.5. The potential impact of Brexit on agri-food trade between Poland and the United

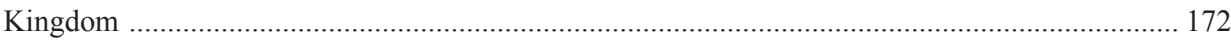

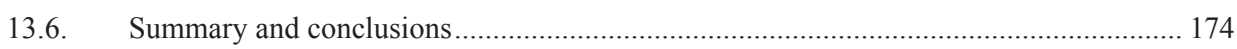

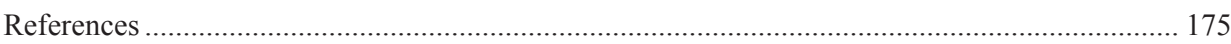

14. The Transatlantic Trade and Investment Partnership (TTIP): a threat or an opportunity for the EU-Mediterranean agriculture and agri-food sector? An exploratory survey ........... 177 Dipl.-Ing. Katja Pietrzyck, PhD Noureddin Driouech, Prof. Brigitte Petersen

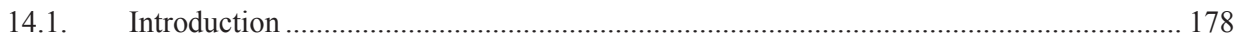

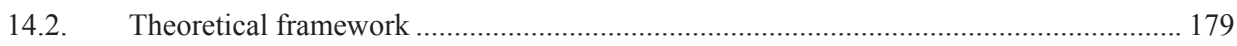

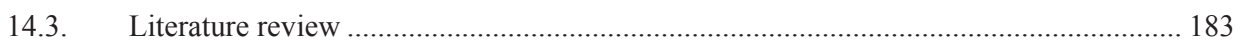

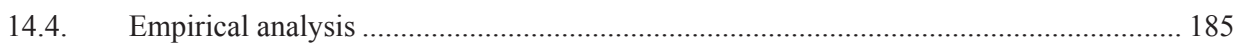

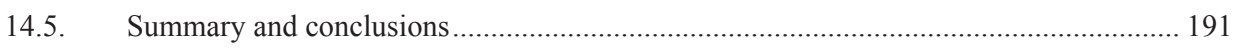

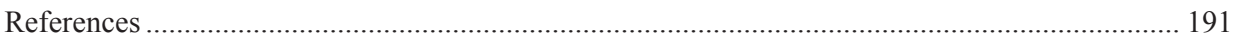

Appendix I: Overview of trade statistics regarding selected products ........................................... 195

15. The concept of short supply chains in the food economy............................................. 196

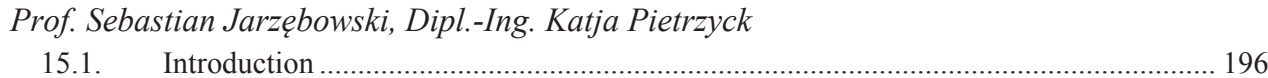

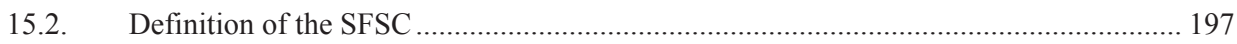

15.3. Development of short supply chains in Europe............................................................. 201

15.4. Global context of European short supply chains ........................................................... 205

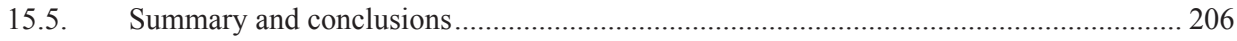

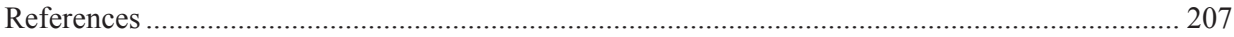

16. The CAP implementation in Wallonia - today performance and questions for the future -

A brief supplementary comment from Warmia and Mazury perspective............................. 209

PhD Philippe Burny, PhD Benon Gazinski

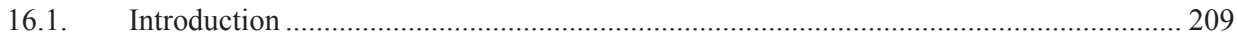

16.2. Implementation of the green payment in Wallonia in 2015 ........................................ 210

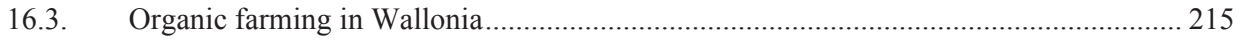

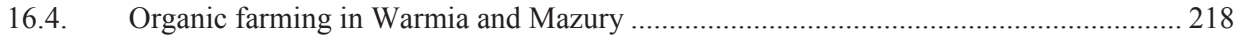

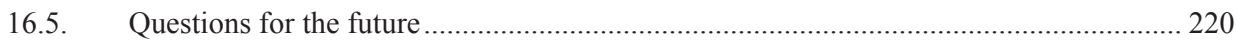

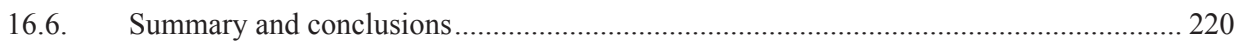

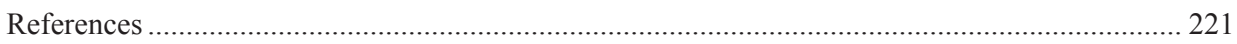

17. Afforestation of agricultural land financed from the RDP 2014-2020 ....................... 224

PhD Marek Zieliński

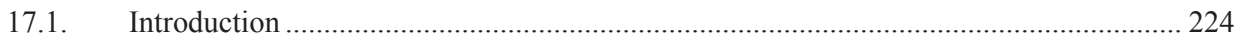

17.2. Natural farming conditions in Poland in regional terms................................................. 225 
17.3. The impact of natural farming conditions in Poland on the economic situation and the possibility of afforestation on farms

17.4. Land afforestation financed from the RDP 2014-2020 in regional terms

17.5. Importance of land afforestations financed under the RDP 2014-2020 in the EU climate policy for 2021-2030.

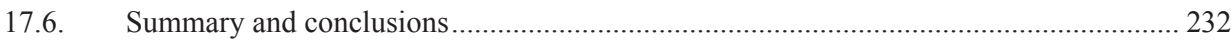

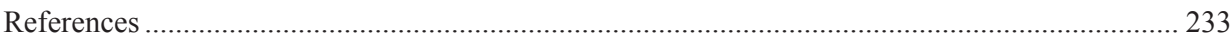

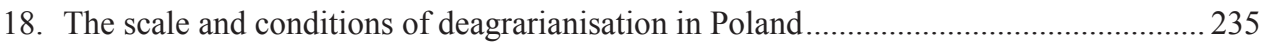

PhD Michat Dudek, PhD Bożena Karwat-Woźniak

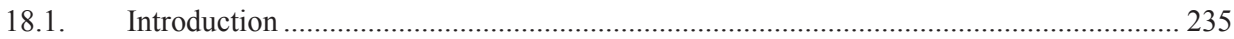

18.2. The conditions of the decrease in employment in agriculture ......................................... 236

18.3. The change in the scale of employment in agriculture in Poland and its conditions....... 238

18.4. The instruments of the Cohesion Policy and agriculture and rural development of the EU

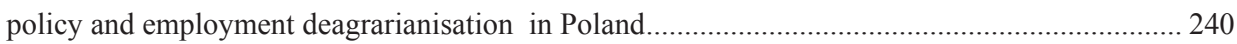

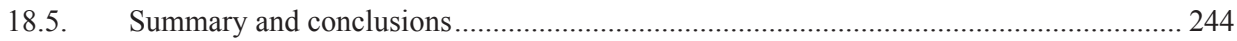

References 245

19. Socio-economic and environmental parameters and results of rural development under the CAP: the case of Bulgaria ................................................................................................ 247 Prof.dr.hab. Julia Doitchinova, Prof.dr.hab. Ivan Kanchev, Ass.Prof. Ralitsa Terziyska PhD, Ass.Prof. Kristina Todorova PhD

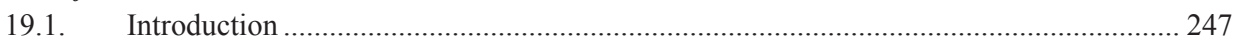

19.2. Changes in Bulgarian rural areas - socio-economic and environmental aspects................ 248

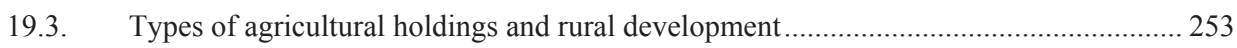

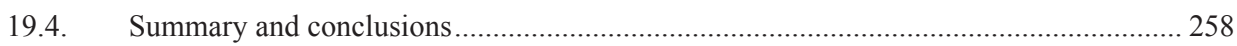

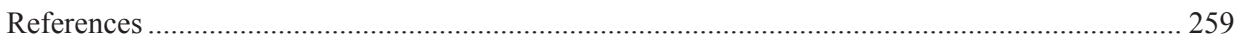

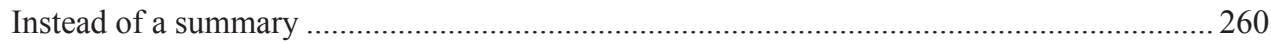

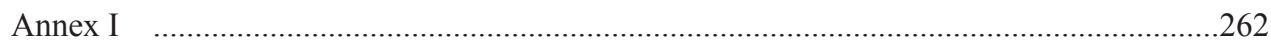




\title{
16. The CAP implementation in Wallonia - today performance and questions for the future - $A$ brief supplementary comment from Warmia and Mazury perspective
}

\author{
PhD Philippe Burny ${ }^{1,2}$, PhD Benon Gazinski ${ }^{3}$ \\ ${ }^{1}$ Walloon Agricultural Research Center, Gembloux, Belgium. Email: \\ ${ }^{2}$ University of Liège, Gembloux Agro-Bio Tech, Gembloux, Belgium \\ ${ }^{3}$ Institute of Political Science, University of Warmia and Mazury \\ p.burny@cra.wallonie.be,begaz@uwm.edu.pl
}

DOI: $10.30858 / \mathrm{pw} / 9788376587431.16$

\begin{abstract}
The new Common Agricultural Policy was defined in 2013, with a stronger emphasize on the environment and the introduction of the "green payment", as well as a clear support for organic farming. This paper examines how the green payment was implemented for the first time in Wallonia (South of Belgium, one of the founders of the European Union) and shows the situation in both Wallonia and the Warmia and Mazury voivodeship in Poland, a new EU Member State. It appears that agriculture in both regions is on the way towards a more sustainable development model, though the future is more uncertain than ever.
\end{abstract}

Keywords: CAP, organic farming, green payment, Wallonia, Warmia and Mazury, JEL codees: Q18, Q50, Q58, Q14

\subsection{Introduction}

Sustainability is a challenge for the European agriculture: better solutions must be implemented in order to develop economic activities and create jobs while respecting the natural resources [Cvik and MacGregor Pelikanova, 2015]. The current version of the Common Agricultural Policy, decided in 2013 and implemented since 2015, is the result of three years of difficult negotiations [Bureau, 2012]. One of its most important features is that it goes further than ever in favour of the environment [Matthews, 2013]. The so-called green payment, which must account for $30 \%$ of all direct payments in every EU Member State was established [Hart, 2015], proving that the relation between agriculture and environment is becoming a priority in the EU and international policies [Brezuleanu et al., 2013; Gazquez-Abad et al., 2011]. In addition, the CAP is also supporting organic farming, which is now considered as a trustable opportunity for a more sustainable development model all over the world [Dufumier, 2012; Petrescu et al., 2015] and is also more and more popular among consumers 
[Petrescu et al., 2014] because they think that organic products can preserve their health and the environment [Petrescu and Petrescu-Mag, 2015] or have better sensory attributes [Bryła, 2016; Tobler et al., 2011].

Organic farming must be now considered in a broader context than agriculture itself: it also takes into account rural development, the environment and the society. Organic farming appeared in Wallonia in the 1980s [Burny and Gellens, 1988] and the first European legislation concerning organic farming was published in 1991, just one year before the MacSharry's reform of the CAP.

In such a rapidly and deeply changing context, the paper will examine the results of the implementation of the green payment in Wallonia and also the evolution of organic farming in this Southern region of Belgium, on the one hand, and the situation of organic farming in Warmia and Mazury, a province of a new EU Member State, Poland, on the other. Finally, some considerations regarding the future are presented.

\subsection{Implementation of the green payment in Wallonia in 2015}

The difficult political agreement, which was finally reached in June 2013, led to four legal texts including the Regulation (EU) No. 1307/2013 of December 17, 2013, dealing more specifically with direct payments to farmers [Burny and Terrones Gavira, 2016]. A new architecture for direct payments was defined, leaving important decisions (some measures are optional and the relative importance of each of them can vary) to the Member States or the regions within them [Hart, 2015]. There is, however, one exception: the green payment, which has to account for $30 \%$ of the national/regional envelope for direct payments in each Member State/region. This is compulsory. Indeed, the green payment is considered as very important measure for the environment and the fight against climatic change.

In Wallonia, the new structure of the direct payments [Arrêté du Gouvernement wallon du 12 février 2015; Arrêté ministériel du 23 avril 2015], after notification to the Commission and its approval, especially about coupled payments (whose percentage in the total amount for direct payments is higher than the normally authorized one and needed a special approval by the Commission, but respecting the new regulation), is presented in Figure 1.

How to grant the green payment was the decision of the Member States/regions: either proportionally to the basic payment, or in the same amount for each eligible hectare. The Walloon government chose the first option, in order to avoid too rough changes for some farmers compared to the previous period of 2007-2013. 
In addition, every year before August $1^{\text {st }}$, and for implementation the following year, each Member State/region can inform the Commission that the implementation ways of the greening will be changed.

Figure 1. New architecture of direct payments in Wallonia (2015-2020)

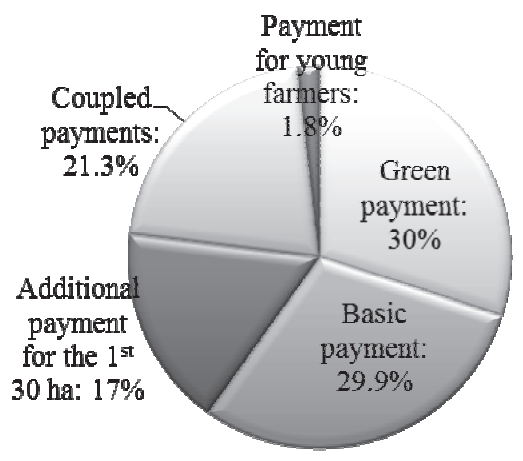

Source: Burny and Terrones Gavira [2015].

More specifically, the green payment is linked to three conditions (Article 43 of Regulation (EU) No. 1307/2013):

- Maintenance of permanent pastures,

- Crop diversification,

- $\quad$ Presence of an ecological focus area.

It is worth to note that organic farmers automatically get the green payment without any additional constraints and so they do not have to respect the three of the above-mentioned conditions.

\section{Maintenance of permanent pastures}

Permanent pastures are grassland since at least five years.

The reference year being 2015, each Member State/region establishes the reference ratio as the area of permanent pastures divided by the total agricultural area, at the national/regional or farmer's level. Wallonia chose the regional level.

In the future, the reference ratio cannot decrease by more than $5 \%$.

The Member State/region must also define the permanent pastures which are considered as environmentally fragile. These areas cannot be ploughed or transformed for another purpose (Article 45).

In Wallonia, these permanent pastures are all situated in the Natura 2000 site.

\section{Crop diversification}

In order to get the green payment, farmers have to practice crop diversification if: 
- They have between 10 and 30 ha of arable land: in such a case, they must have at least two crops, the most important not exceeding $75 \%$ of the area of arable land;

- $\quad$ They have more than 30 ha of arable land: in such a case, they must have at least three crops, the most important covering no more than $75 \%$ of the arable land area, and the two most important no more than $95 \%$.

The following can be considered as "crops": land lying fallow, temporary pastures, one gender considered in the botanical classification (Triticum, Hordeum, Beta,...) or one species for Brassicaceae, Solanaceae and Cucurbitaceae.

No diversification is requested in the following cases:

- $\quad$ The farmer has less than 10 ha of arable land;

- More than $75 \%$ of the arable land are devoted to the production of grass (temporary pastures) or fallow and, at the same time, the remaining arable land area does not exceed 30 ha;

- More than $75 \%$ of the total agricultural area of the farm are devoted to permanent pastures or the production of grass and, at the same time, the remaining arable land area does not exceed 30 ha.

According to the area declaration of farmers for 2015, in Wallonia 50\% of the farmers were not submitted to crop diversification, while $16 \%$ were obliged to have at least two crops on their arable land and 33\% had the strongest obligation: to have at least three crops on their arable land. Around 100 farms (less than 1\%) failed to meet the criteria (Figure 2).

Figure 2. Number of farms towhich applies crop diversification in Wallonia in 2015

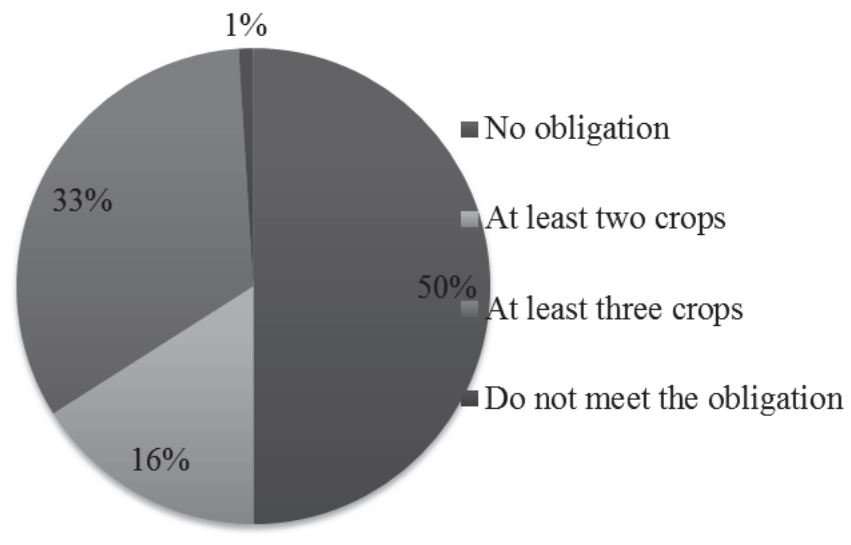

Source: Terrones Gavira, Burny and Lebailly [2016]. 


\section{The ecological focus area}

According to Article 46 of Regulation (EU) No 1307/2013, farmers must devote at least $5 \%$ of their arable land to ecological focus areas when they have more than 15 ha of arable land.

The Member States/regions can choose which are ecological focus areas from the following list (Commission Delegated Regulation (EU) No. 639/2014):

- $\quad$ land lying fallow;

- terraces;

- $\quad$ landscape features, including such features adjacent to the arable land of the holding;

- buffer strips;

- hectares of agro-forestry;

- $\quad$ strips of eligible hectares along forest edges;

- $\quad$ afforested areas;

- $\quad$ areas with catch crops, or green cover (subject to the application of weighting factors);

- $\quad$ areas with nitrogen-fixing crops.

In Wallonia, all the above-mentioned points are considered as ecological focus areas, with the exception of terraces and afforested areas.

Some elements are directly converted into ecological focus areas, but others, like isolated trees for example, need a conversion coefficient to be considered as an ecological focus area (Table 1).

According to Table 1, it means, for example, that an isolated tree cover with an area of $20 \mathrm{~m}^{2}$ on average has an influence on $20 \times 1.5=30 \mathrm{~m}^{2}$ (protection against winds, shadow, etc.).

In Wallonia in $2015,54 \%$ of the farmers were not obliged to have ecological focus areas (they have less than 15 ha of arable land, these were organic farmers).

Among the remaining 5828 farmers, $47 \%$ devoted between 5 and $6 \%$ of their arable land to ecological focus areas, $21 \%$ had between 6 and $7 \%$ and $29 \%$ had more than $7 \%$. A small number of farmers (2.4\%) did not reach the minimim $5 \%$.

The mean of ecological focus areas reached $6.9 \%$, and the median was at $6 \%$.

When farmers had at least $5 \%$ of ecological focus areas, it is observed that $79 \%$ of them declared only one element, mainly catch crops or green cover (95\% of the cases) and $15 \%$ had only two elements.

As far as the area was concerned (Figure 3), catch crops or green cover represented an overwhelming share of $88.8 \%$ of the total ecological focus area in Wallonia. Far behind, came land lying fallow (4.1\%) and nitrogen-fixing crops $(3.7 \%)$. The landscape features were marginal and represented only $2.1 \%$. 
Table 1. Conversion coefficients and weighting factors to transform some areas and landscape features into ecological focus areas

\begin{tabular}{|c|c|c|c|c|c|c|}
\hline Element & Particularity & \multicolumn{2}{|l|}{ Description } & $\begin{array}{l}\text { Conversion } \\
\text { coefficient }\end{array}$ & $\begin{array}{l}\text { Weighting } \\
\text { factors }\end{array}$ & $\begin{array}{l}\text { Ecological } \\
\text { focus area } \\
\left(\mathrm{m}^{2}\right)\end{array}$ \\
\hline \multirow{8}{*}{$\begin{array}{l}\text { Surface } \\
\text { elements } \\
\text { (ha) }\end{array}$} & \multirow{5}{*}{ Plot } & Land lying fallow & $\begin{array}{l}\text { per } \\
1 \mathrm{~m}^{2}\end{array}$ & $\mathrm{n} / \mathrm{a}$ & 1 & 1 \\
\hline & & $\begin{array}{l}\text { Areas with short } \\
\text { rotation coppice }\end{array}$ & $\begin{array}{l}\text { per } \\
1 \mathrm{~m}^{2}\end{array}$ & $\mathrm{n} / \mathrm{a}$ & 0.3 & 0.3 \\
\hline & & $\begin{array}{l}\text { Areas with nitro- } \\
\text { gen-fixing crops }\end{array}$ & $\begin{array}{l}\text { per } \\
1 \mathrm{~m}^{2}\end{array}$ & $\mathrm{n} / \mathrm{a}$ & 0.7 & 0.7 \\
\hline & & Buffer strips & $\begin{array}{l}\text { per } \\
1 \mathrm{~m}^{2}\end{array}$ & $\mathrm{n} / \mathrm{a}$ & 1.5 & 1.5 \\
\hline & & $\begin{array}{l}\text { Strings of eligible } \\
\text { hectares along } \\
\text { forest edges - } \\
\text { without produc- } \\
\text { tion }\end{array}$ & $\begin{array}{l}\text { per } \\
1 \mathrm{~m}^{2}\end{array}$ & $\mathrm{n} / \mathrm{a}$ & 1.5 & 1.5 \\
\hline & $\begin{array}{l}\text { Intercrop } \\
\text { plot }\end{array}$ & $\begin{array}{l}\text { Areas with catch } \\
\text { crops or green } \\
\text { cover }\end{array}$ & $\begin{array}{l}\text { per } \\
1 \mathrm{~m}^{2}\end{array}$ & $\mathrm{n} / \mathrm{a}$ & 0.3 & 0.3 \\
\hline & & Ponds & $\begin{array}{l}\text { per } \\
1 \mathrm{~m}^{2}\end{array}$ & $\mathrm{n} / \mathrm{a}$ & 1.5 & 1.5 \\
\hline & & $\begin{array}{l}\text { Group of } \\
\text { trees/field copses }\end{array}$ & $\begin{array}{l}\text { per } \\
1 \mathrm{~m}^{2}\end{array}$ & $\mathrm{n} / \mathrm{a}$ & 1.5 & 1.5 \\
\hline & Tonogranhic & Field margin & $\begin{array}{l}\text { per } \\
1 \mathrm{~m}\end{array}$ & 6 & 1.5 & 9 \\
\hline elements & elements & Ditches & $\begin{array}{l}\text { per } \\
1 \mathrm{~m}\end{array}$ & 3 & 2 & 6 \\
\hline & & $\begin{array}{l}\text { Hedges/wooded } \\
\text { strips }\end{array}$ & $\begin{array}{l}\text { per } \\
1 \mathrm{~m}\end{array}$ & 5 & 2 & 10 \\
\hline $\begin{array}{l}\text { Punctual } \\
\text { (nb) }\end{array}$ & & Isolated tree & $\begin{array}{l}\text { per } \\
\text { tree }\end{array}$ & 20 & 1.5 & 30 \\
\hline
\end{tabular}

Source: Terrones Gavira et al. [2016]. 
Figure 3. Area of the different types of ecological focus areas in Wallonia in 2015

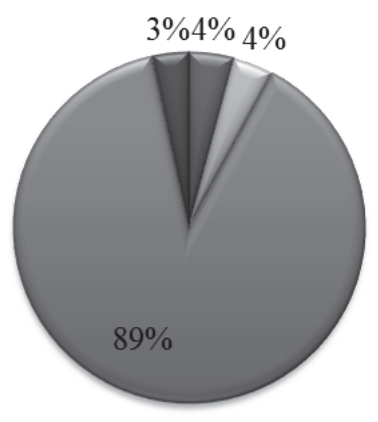

\author{
Land laying \\ fallow \\ $\square$ Nitrogen-fixing \\ crops \\ $\square$ Catch crops \\ a Others
}

Source: Terrones Gavira, Burny and Lebailly [2016].

\title{
16.3. Organic farming in Wallonia
}

Evolution of the number of organic farms and of the organic agricultural area

The evolution of the number of organic farms and of the corresponding area is illustrated in Figure 4. The evolution was rather slow during the first years of the $21^{\text {st }}$ century; however, an acceleration is clearly observed since 2005, with a continuous positive trend. In 2016, the total number of organic farms reached 1493 (+146 compared to 2015) and the corresponding agricultural area reached 71289 ha (+12.4\% compared to 2015), representing, respectively, $12 \%$ of the total number of farmers and $10 \%$ of the total agricultural area.

Figure 4. Evolution of the number of organic farms and organic farming area in Wallonia from 2000 to 2016

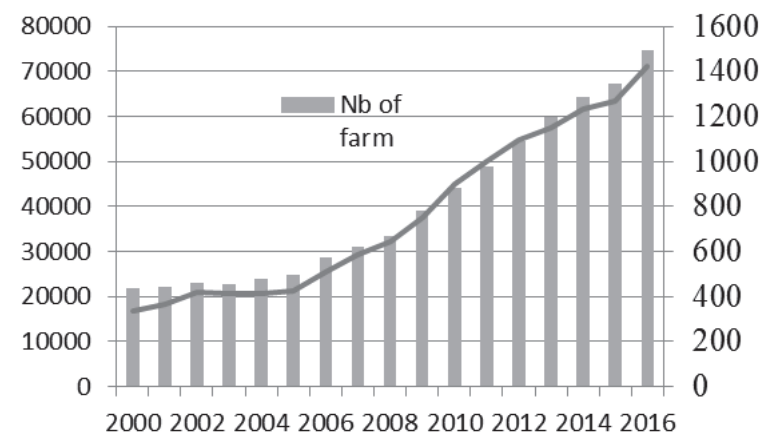

Source Biowallonie [2017]. 


\section{Public support}

This success is partially due to the strong public support which is granted to organic farming. In 2016, organic farming was clearly defined as a tool within the "Walloon strategy for sustainable development", while in 2013 was launched the "Walloon strategic plan for the development of organic farming towards 2020" [Comase and Di Antonio, 2013].

Within the CAP and its second pilar, rural development, the financial support granted to organic farming is presented in Table 2 .

The support is additional to direct payments and is even higher for farmers in transition from conventional to organic methods.

Table 2. Financial support (EUR/ha) for organic farming in Wallonia (2015-2020)

\begin{tabular}{|l|c|c|c|}
\hline \multirow{2}{*}{ Crops } & \multicolumn{2}{|c|}{ Area of organic farming } \\
\cline { 2 - 4 } & \multicolumn{2}{|c|}{0 to 60 ha } & \multicolumn{2}{c|}{ over 60 ha } \\
\hline Meadows and forage crops & 200 & 320 \\
\hline Other annual crops & 0 to 3 ha & 3 to 14 ha & over 14 ha \\
\hline & 900 & 750 & 400 \\
\hline $\begin{array}{l}\text { Fruit trees, horticulture and } \\
\text { seed production }\end{array}$ & & & \\
\hline
\end{tabular}

Source of the basic data: Service public de Wallonie [2015].

\section{Evolution of the consumption of organic products}

\section{Market share of organic products in the Belgian food market}

The market share of organic products in the Belgian food market continuously increased between 2008 and 2016, from 1.5 to 3.2\% (Figure 5).

Figure 5. Evolution of the market share of organic products in the Belgian food market (\%)

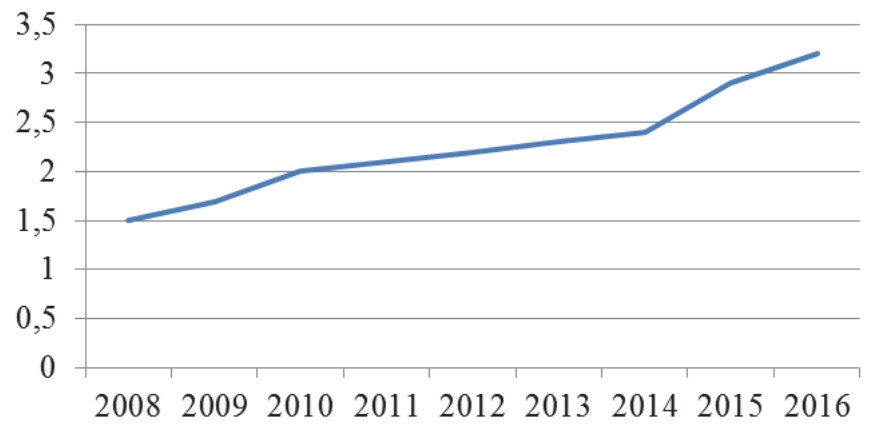

Source of basic data: Biowallonie [2017]. 
Organic food products, though more expensive than conventional products, are more and more popular; this phenomenon even accelerated during the last two years. In the future, this share could continue to increase as it reached 8.4\% in Denmark in 2015 (the highest in Europe) or 7.7\% in Switzerland and $4.8 \%$ in Germany [Biowallonie, 2017]. So, the target of $3.0 \%$ in 2020 defined in the Walloon development plan for organic farming has already been reached.

The market share of organic products is very variable according to the type of products (Figure 6). However, it increased for all products with the exception of bread [Burny, 2017].

As prices are very different from one product to another, the position of one product regarding the market share can be different from the position regarding expenses per capita. The highest market shares are observed for meat substitutes (a product which is not popular) and eggs (a cheap product), before vegetables and fruit, which are well known organic products. The market share for dairy products reached $3.0 \%$ while the expenses for dairy products are the highest, the prices per unit being higher than for other food products. Globally, the share of vegetal products is higher in the organic food market than in the conventional one.

Figure 6. Market share of organic products in 2010 and 2016 (\%)

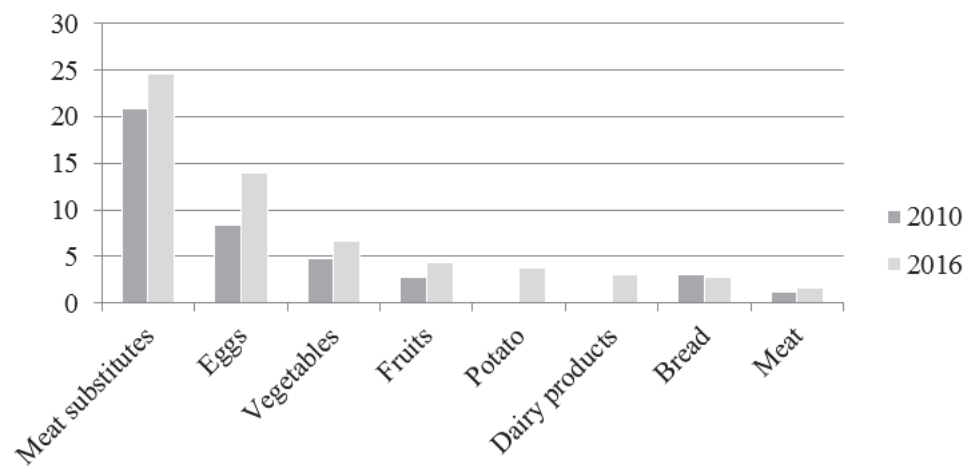

Source of basic data: Biowallonie [2017].

Compared to the situation of 2010, it appears that the market shares significantly increased, with the exception of bread. For dairy products, data are available for 2014, 2015 and 2016, showing an important increase: $2.1 \%$ in $2014,2.7 \%$ in 2015 and $3.0 \%$ in 2016 . For potato, no trend could be observed during the period between 2013 and 2016. So, it is clear that vegetables, fruit and dairy products show a strong and continuous positive trend in their demand. 


\subsection{Organic farming in Warmia and Mazury}

Region of Warmia and Mazury, placed in North-Eastern Poland, occupies the top place in the country by territory, but it is relatively low as the population is concerned. It is mainly due to peculiarities of the natural conditions: large percentage of forests and grassland, numerous lakes ("one thousand lakes" country - as a matter of fact it is more than double of that) and other factors, including climate, soils and terrain relief.

The region is well-known for its remarkable recreation of properties, but while social and economic conditions are concerned, the overall picture is not encouraging. High unemployment rate, lower GDP/capita or average incomes are a few of many indicators confirming that this area belongs to the least developed in Poland and even one of the less developed regions on the EU scale.

Turning to agriculture, natural conditions, lower population density and the heritage of the past (ca. $50 \%$ of agricultural land belonging to the state farm sector, more than double of the national average) results in differences in farm structure - the average farm is more than two-fold larger than the country average.

Figure 7. Number of organic producers in Poland in 2016

Source: IJHARS [2017].

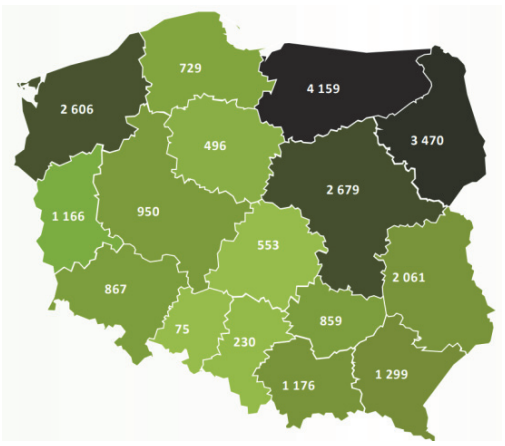

Figure 8 . Areage of organically cultivated agricultural land in 2016 (ha)

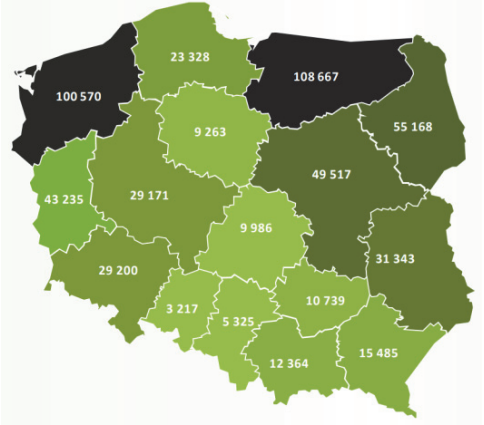

Source: IJHARS [2017].

As can be seen from the Figures 7 and 8, the voivodeship occupies the leading place in the country both as regards the number of organic producers and the area of agricultural land under organic farming. This position is confirmed by steady increase in the share of organic producers in the total number for Poland: from $7.05 \%$ in 2007 to $14.84 \%$ in 2016 , more than two-fold growth during the period of only 9 years. Similar picture can be observed while taking into account the share of organically cultivated land in the province in the total country acreage of organically cultivated land - during the same period of 9 years, 2007 vs 2016 one can observe the increase from 5.35 to $10.28 \%$, respectively. 
More careful insight, critical examination of the statistical data at the farm gate level and offices of different institutions involved leads to defining some problems making such an overall optimistic picture more complex and less optimistic:

- $\quad$ Large scale of the organic farming practices in Warmia and Mazury voivodeship is not entirely due to the large territory of the region and its specific environmental conditions. Some decline of an acreage of organically cultivated land, observed in recent years (2014 and 2015) calls, therefore, for an explanation.

In the region, there are some landowners from far away, who just own land and are rather not interested in agricultural production at all. They focus mainly on "harvesting" money from the EU budget. Examples:

(i) walnut, or other sophisticated plants cultivation - just to fill required data into the application form to get subsidies - with production even at null level!;

(ii) grassland - cut but no grass being used as an animal feed.

Such unhonest practices are now remarkably reduced because of an introduction of more effective control measures, like present requirement to keep some farm animals. Nevertheless, some are capable to continue their practice because of 5-year long period of former declarations.

- $\quad$ Under the new 2015package, forage plants introduction resulted in reduced level of payments for farmers of concern, in some cases even to ca. $60 \%$.

- There are some 18 different payment options for organic farmers. Too many, making the overall picture complex and too difficult for an average farmer to comprehend and follow. Simplification of the CAP procedures is one of the declared objectives of ongoing adjustments but just opposite is often seen from the farmer's perspective.

- Organic farmers are susceptible to crop failures due to different agents: droughts, water-logging or pest invasion - no effective compensation measures are available.

- $\quad$ It is difficult to meet some criteria related to animal breeding. Procedures related to the purchase of new animals last too long.

- $\quad$ Organic raw materials and marketing of manufactured goods are a severe bottleneck. Large amounts of farm output are sold as unprocessed commodity. Customer, arriving to - say - the "Lidl" market in Olsztyn, could meet rather German organic products on the shelves. In some cases, raw materials (like cereals) are sold to Germany and - after manufacturing sent back to Poland. 


\subsection{Questions for the future}

The proceeding lines proved that things are changing more and more quickly. For agriculture in general, the future is more and more uncertain and the farming business is more and more risky. This is due in particular to price volatility, which makes income impossible to predict, organic farming included.

A very important topic is the future of direct payments, partially linked to the CAP budget. What about their future distribution among and within the Member States? Will they take into account the labour force? Will the coupled payments remain or be suppressed? Will the payments for the first hectares increase, as $20 \%$ of the benefiters still get $80 \%$ of the total amount of direct payments?

The role of farmers' associations will probably be reinforced within the value chain, allowing the farmers to keep a better share of the added value, in a food market where processed products are very important. However, the processing industry and the supermarkets are also becoming larger, so that the negotiating position of the producers is not always favourable, especially in a period of overproduction.

However, a contradictory trend is the phenomenon of direct sales and local consumption. Circular economy is also up-to-date. But what will be their success? Surely there is a specific niche for these initiatives, but to which extent? It is also the question for specific quality products. There is a market for these products, but it does not represent the bulk of production. It is the case for organic farming. It has a role to play, but can we imagine that the whole agricultural production would come from organic farming?

In a world of an always tougher competition, the classic production cost reduction will surely remain very important. In this context, is it wise to invest more or, on the contrary, to invest less in order to avoid a too heavy indebtedness? The public investment support policy should be more careful, not leading farmers to invest too much and be too indebted when farm income is so variable and unpredictable.

In a period of so many uncertainties, what about family farms? Will they survive, or will the farming activity be taken over by capitalistic large companies, so threatening our European farming model?

All these questions are open, and the answers will be given by the citizens' will.

\subsection{Summary and conclusions}

The implementation of the new CAP in Wallonia has been successful and stressed the role of the environment through the green payment, ecological focus areas and organic farming. As it is also the case in Warmia and Mazury, organic 
farming presents today a significant share of the total number of farmers and of the total agricultural area. It so appears clearly that European agriculture, through these examples, is going towards a more sustainable development model. However, several problems and questions are still ahead. It is obvious that this positive evolution is significantly due to a strong public support and not only to the food market orientation or to the conviction of all farmers. The question of the prices paid by consumers is still open as a non-negligible share of the European population is rather poor and could not afford higher food prices. Anyway, the future is more uncertain than ever and there is a strong need for an agricultural policy with clear objectives supported by the EU citizens and provided with sufficient means to reach them.

\section{References}

1. Biowallonie (2015). Les chiffres du bio 2014. Namur, 22 p. [Online], Available: http://www.biowallonie.com/les-chiffres-du-bio-2014/ (accessed: 20 May 2015).

2. Biowallonie (2017). Les chiffres des bio 2016, Namur, 28p.

3. Bryła, P. (2016). Organic food consumption in Poland: Motives and barriers. Appetite, 105:737-746.

4. Bureau, J.C. (2012). The Common Agricultural Policy After 2013, Intereconomics, vol. 6, pp. 316-321, ISBN 978-1-4419-0368-6.

5. Burny, Ph. (2017). Recent evolution of the consumption of organic food products in Belgium. Book of Abstracts of the AGROSYM International conference held in Jahorina, Bosnia and Herzegovina.

6. Burny, Ph., Gellens, C. (1988). L'agriculture biologique: quelques caractéristiques des agriculteurs intéressés par ce nouveau mode de production dans quatre régions agricoles du Sud de pays, Annales de Gembloux. vol. 3. pp 213-220.

7. Burny, Ph., Terrones Gavira, F. (2015). Gainers and losers of the implementation of the new Common Agricultural Policy in Wallonia. Agriculture and Agricultural Sciences Procedia, 7.

8. Burny, Ph., Gaziński, B. (2015). The EU membership vs rural development. A case study of Eastern Poland, [in:] Strategie gospodarcze i społeczne Unii Europejskiej (ed. Opolski K., Górski J.), Wydział Nauk Ekonomicznych Uniwersytetu Warszawskiego, Warszawa 2015, pp. 197-206.

9. Comase and Di Antonio, C. (2013). Plan stratégique pour le développement de l'agriculture biologique en Wallonie à l'horizon 2020, 69 p, Namur [Online], Available: http://agriculture.wallonie.be/apps/spip_wolwin/IMG/pdf/plan_ bio_final_juin_2013.pdf (accessed: 21 May 2015).

10. Commission delegated Regulation (EU) No 639/2014 of 11 March 2014 supplementing Regulation (EU) No. 1307/2013 of the European Parliament and of the Council establishing rules for direct payments to farmers under support schemes within the framework of the common agricultural policy and amending Annex X to that Regulation. OJ L 181, 20.6.2014, p. 1. 
11.Cvik, E.D., MacGregor Pelikánová, R. (2015). Agricultural policy and law as reflected by Websites of Czech organic farmers, Proceedings of the Agrarian perspectives XXIII, Prague, pp. 82 - 89, ISBN 978-80-213-2581-4.

12. Czarkowska , E. (2015). Cultural and natural heritage: between theory and practice, Faculty of Environmental Management and Agriculture, University of Warmia and Mazury, Olsztyn 2015.

13. Dufumier, M. (2012). Famine au Sud, malbouffe au Nord-Comment le bio peut nous sauver, Paris: NiL, 194 p, ISBN 978-2-84111-612-6.

14. Hart, K. (2015). Green direct payments implementation choices of nine Member States and their environmental implications, Institute for European Environmental Policy, London, 75 p. [Online], Available: http://www.eeb.org/index.cfm?Link ServID=0DFEF8B2-5056-B741-DB05EBEF517EDCCB (accessed: 16 May 2015).

15.IJHARS (2017). Raport o stanie rolnictwa ekologicznego w Polsce w latach 2015-2016, The report on organic farming in Poland in 2015-2016 (ed. I. Zdrojewska), IJHARS, Warszawa 2017.

16. Matthews, A. (2013). Greening agricultural payments in the EU's Common Agricultural Policy, Bio-based and Applied Economics, vol. 2(1), pp. 1-27, ISSN 2280-6172.

17.Petrescu, D.C., Petrescu-Mag, R.M. (2015). Organic Food Perception: Fad, or Healthy and Environmentally Friendly? A Case on Romanian Consumers. Sustainability, 7(9):12017-1203.

18.Petrescu, D.C., Burny, Ph., Dragan, A.A., Petrescu-Mag, R.M. (2014). Organic food between consumers' interest and indifference, Sustainable development in conditions of economic instability, 3rd edition, Editura cibernetica Mc Bucuresti 2014, pp. 508-517, ISBN 978-606-8288-04-8.

19. Petrescu, D.C., Petrescu-Mag, R.M., Burny, Ph. (2015). Management of Environmental Security through Organic Agriculture, Contribution of Consumer Behaviour, Environmental Engineering and Management Journal, 14(11): 2625-2636.

20.Przewodnik po działaniu rolnictwo ekologiczne PROW 2014-2020, Ministry for Agriculture and Rural Development. Warszawa 2016.

21.Regulation (EU) No. 1307/2013 of the European Parliament and of the Council of 17 December 2013 establishing rules for direct payments to farmers under support schemes within the framework of the common agricultural policy and repealing Council Regulation (EC) No 637/2008 and Council Regulation (EC) No. 73/2009. OJ L 347, 20.12.2013, p. 608.

22. Service public de Wallonie (2015). Notice explicative de la demande de nouvel engagement en mesures agroenvironnementales et agriculture biologique, $4 \mathrm{p}$. [Online], available: http://agriculture.wallonie.be/apps/spip_wolwin/IMG/pdf/ Notice-mesures-agroenvironementtales-bio.pdf (accessed: 20 May 2015).

23. Terrones Gavira, F., Burny, Ph., Lebailly, Ph. (2016). Etude d'impact du système des paiements directs 2015-2019 en Wallonie et d'éventuelles révisions au cours de cette période, Annexe 1, Impact du verdissement pour les agriculteurs wallons, Unité d'économie et développement rural, Gembloux Agro-Bio Tech, Université de Liège and Service public de Wallonie, 10p. 
24.Tobler, C., Visschers, V.H.M., Siegrist, M. (2011). Eating green. Consumers' willingness to adopt ecological food consumption behaviours. Appetite, 57(3):674-82.

25. Walloon Government (2014). Arrêté du Gouvernement wallon du 15 mai 2014 instaurant le système régional de qualité différenciée pour les produits agricoles et les denrées alimentaires. Moniteur belge du 11 septembre 2014, pp. 71765 71772, [Online], Available: http://www.ejustice.just.fgov.be/cgi/summary.pl (accessed: 24 May 2015).

26. Walloon Government (2014). Décret du 27 mars 2014 relatif au Code wallon de l'Agriculture Moniteur belge du 5 juin 2014, pp. 42894 - 43085 [Online], Available: http://agriculture.wallonie.be/codeagricole/ (Accessed: 24 May 2015). 